\title{
Seat-belt use among drivers and front passengers: an observational study from the Islamic Republic of Iran
}

\author{
F. Sadeghnejad, ${ }^{1}$ S. Niknami, ${ }^{1}$ A. Hydarnia ${ }^{1}$ and A. Montazeri ${ }^{2}$
}

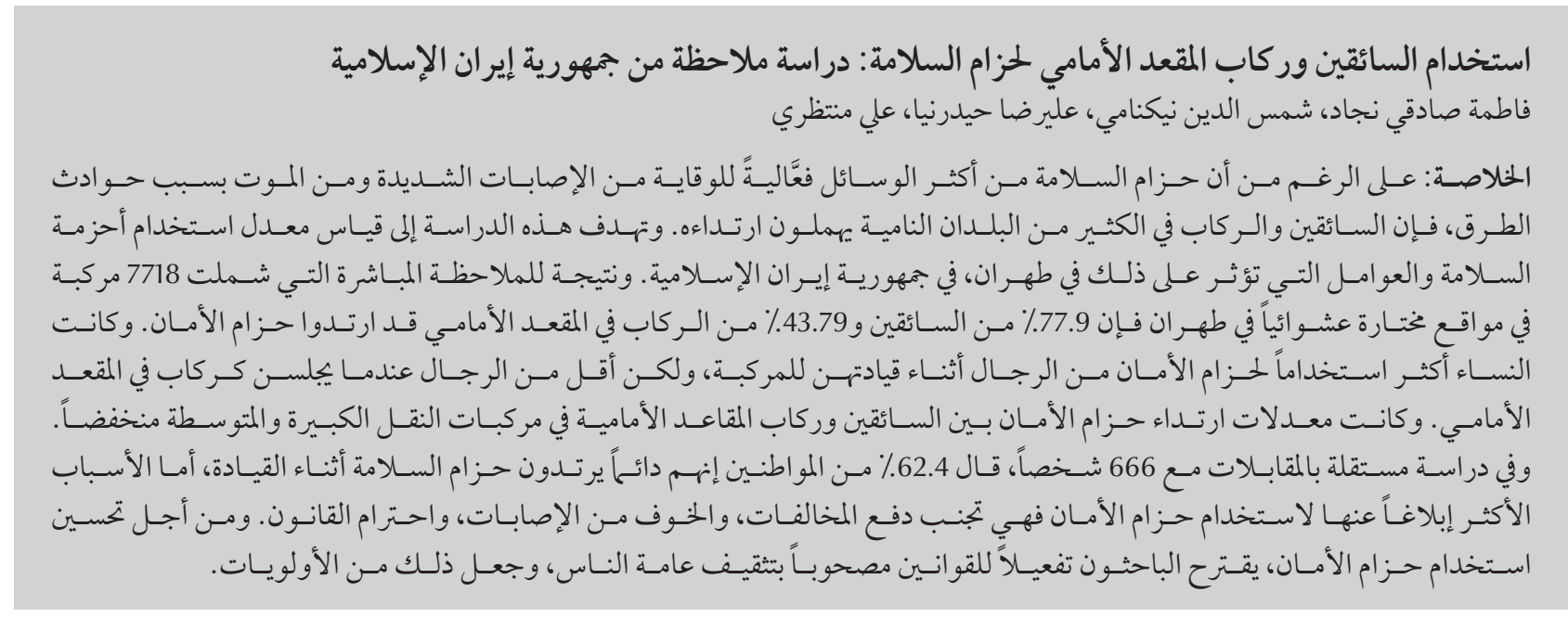

ABSTRACT Although seat-belts are the most effective means of preventing severe injuries and deaths from road accidents, drivers and passengers in many developing countries neglect to wear them. This study aimed to measure the rate of use of seat-belts and factors affecting their use in Tehran, Islamic Republic of Iran. In direct observations of 7718 vehicles at randomly selected sites in Tehran, $77.9 \%$ of drivers and $43.7 \%$ of front passenger had seat-belts fastened. More women used seat-belts than did men while driving but fewer as front-seat passengers. Rates of seat-belt wearing among both drivers and front passengers of vans and pick-up vehicles was low. In a separate interview study of 666 citizens, $62.4 \%$ stated that they always wore seat-belts while driving. The most frequently reported reasons for using seat-belts were avoiding fines, fear of injuries and respecting the law. To improve seatbelt use, it is recommended that law enforcement accompanied by public education should be a priority.

Utilisation de la ceinture de sécurité chez les conducteurs et les passagers assis à l'avant : étude d'observation en République islamique d'Iran

RÉSUMÉ Le port de la ceinture de sécurité est le moyen le plus efficace pour la prévention des traumatismes sévères et des décès dans les accidents de la circulation. Pourtant, les conducteurs et les passagers de nombreux pays en développement négligent cet acte. La présente étude visait à mesurer le taux d'utilisation de la ceinture de sécurité et les facteurs influant sur celle-ci à Téhéran (République islamique d'Iran). À partir de l'observation directe de 7718 véhicules sur des sites sélectionnés aléatoirement à Téhéran, il a été constaté que 77,9\% des conducteurs et $43,7 \%$ des passagers assis à l'avant avaient bouclé leur ceinture. Les conductrices étaient plus nombreuses à mettre leur ceinture que les conducteurs mais moins nombreuses à porter la ceinture de sécurité en tant que passagères assises à l'avant. Dans les fourgons et les camionnettes, les taux d'utilisation de la ceinture chez les conducteurs comme chez les passagers des sièges avant étaient faibles. Dans une étude par entrevues distincte au cours de laquelle 666 personnes ont été interrogées, 62,4\% ont déclaré toujours porter leur ceinture de sécurité lorsqu'elles conduisaient. Les motifs les plus fréquemment évoqués pour justifier le port de la ceinture étaient les suivants : éviter les amendes, craindre les traumatismes et respecter la loi. Afin d'améliorer le port de la ceinture de sécurité,il est recommandé que l'application de la loi et l'éducation du public deviennent des priorités.

${ }^{1}$ Department of Health Education. School of Medical Sciences, Tarbiat Modares University, Tehran, Islamic Republic of Iran (Correspondence toS. Niknami:niknamis@modares.ac.ir). ${ }^{2}$ Mental Health Research Group, Health Metrics Research Centre, Iranian Institute for Health Science Research, Academic Centre for Education, Culture and Research, Tehran, Islamic Republic of Iran.

Received: 19/06/13; accepted: 16/01/14 


\section{Introduction}

Fatalities and injuries caused by road traffic crashes are among the main challenges of public health (1). In the Eastern Mediterranean Region overall the fatality rate is about 26.4 per 100000 people, while in the Islamic Republic of Iran fatalities from road accidents are 39 per $100000(1,2)$. The United Nations declared the years 2010-2020 as the Decade of Action for Road Safety, and asked its Member States to pay close attention to the main risk factors for road traffic injuries (3). Recent studies have found that three-fifths of road accidents are due to behavioural factors (4) and among the indicators of the Road Safety Development Index, road users' behaviour is at the heart of road safety development (5). Wearing a safety seat-belt is considered the main factor in reducing the severity of vehicle accident injuries $(1,6)$. It has been shown that the use of seat-belts reduces the risk of death in drivers and front-seat passengers by about $40 \%$ to $50 \%$ and the severity of injuries by about $50 \%$ (7).

In the Islamic Republic of Iran about $87.6 \%$ of road traffic injuries are head injuries $(8,9)$ and, in view of the low quality of management after accidents (10,11), we should consider more seriously protective measures such as seat-belt use to reduce the severity of injuries and prevent deaths (12). According to a recent survey, seat-belt wearing was found to be the most important factor affecting road safety in the Islamic Republic of Iran (13). Unfortunately, previous studies have shown the rate of seat-belt use in the country is still very low. In 2009 only $35 \%$ of Iranian people were using a seat-belt (14). Recent studies have estimated safety-belt use at about $52 \%$ to $63 \%$ (15), whereas the rate in developed countries is over 93\% (7). Tehran, with over 11 million population and 4 million vehicles, is one of the busiest capitals in the world. The incidence of unintentional injuries in Tehran is 28.1 per 1000 people, half of which are related to traffic accidents (16). The Iranian legal medicine organization reported that from March 2011 to March 2012, only in Tehran province, 1609 people died in traffic accidents and nearly 34000 people were injured. According to the traffic police of Tehran, among all crash fatalities in 2011, only $30 \%$ had fastened seat-belts, and the main reason (more than $59 \%$ of cases) for fines for road traffic violations of Tehran drivers was notfastening seat-belts (17). Over $75 \%$ of traffic fatalities occurred in the inner city. In other words, Tehran is the only province in the Islamic Republic of Iran in which inner-city traffic fatality is higher than outside the city limits (18).

The current study is part of a larger study that aimed to identify the epidemiological, environmental and behavioural determinants of safety-belt use among people living in Tehran in order to develop a theory-based educational intervention. The main study is currently underway, and the results are yet to be published. Thus, the particular objectives of this study was to observe current conditions and determine common reasons and factors related to use and non-use of safety-belts in Tehran, Islamic Republic of Iran.

\section{Methods}

This was a cross-sectional study of the use of seat-belts by people living in Tehran. It consisted of 2 parts: an observational study to obtain an estimation of seat-belt use among drivers and front passengers while on the road; and an interview-based survey about individuals' reasons for wearing and not wearing seat-belts.

\section{Observational study}

We selected 11 observation sites by using a stratified multistage sampling method. First, we divided Tehran into 5 major geographical regions (north, south, east, west, and centre). Then, from each region, 2 roads were selected randomly from the list of all roads in the region (in all 10 roads). In addition, due to the importance of highways in the traffic flow of Tehran 1 of the inner-city highways was selected.

The data were collected by an observational checklist specially designed for this study guided by the principle documents of the $\mathrm{WHO}$ (7), the Centers for Disease Control and Prevention (19) and the National Highway Traffic Safety Administration $(20,21)$. A team of trained observers recorded the type of vehicle, and the sex and estimated age of drivers and front-seat passengers and whether they were wearing a seatbelt or not. The observations were planned from 7 to 12 July 2012 for 6 days (Saturday to Thursday) from 08:00 to 09:00 hours (at peak hours) and for all lanes (i.e. outer, middle and edge) in a road.

The data were analysed using a descriptive reporting on numbers and frequencies and the chi-squared test for comparing categorical data.

\section{Interview-based study}

A brief interview was carried out with pedestrians at 11 sites (as indicated above) for 1 week from 09:00 to 10:00. They were approached in the street and interviewed by trained interviewers. The only criterion for inclusion was the consent of the participant.

For data collection, the research team developed a semi-structured questionnaire and a team of experts assessed its content validity (22). We asked each participant to indicate how often he or she used a vehicle seat-belt (either as a driver or the front passenger). Response categories ranged from always to never. Then they were asked about reasons for using and 
not using safety-belt. The interviewees could choose more than 1 response from a list of different options.

We used descriptive statistics with numbers and frequencies to report on frequency of seat-belt use and reasons for using or not using seat a belt while driving.

\section{Results}

\section{Observational study}

In all we observed 11483 individuals (7718 drivers and 3765 front-seat passengers). Most drivers were male (90.2\%), whereas only $62.9 \%$ of front passengers were men (Table 1).

Our observations showed that $77.9 \%$ of drivers were using a seatbelt. The seat-belt use in drivers and front passengers by age, sex, vehicle type and observation site are shown in Table 2. The rate of seat-belt wearing among women drivers was higher than among men $(81.0 \%$ versus $77.5 \%)$. The seat-belt use of taxi and private car drivers was high (81.9\% and $80.6 \%$ respectively), but among pick-up and van drivers, seat-belt use was lower (52.8\% and $61.0 \%$ respectively). Wearing safety-belts among drivers varied across different observation sites of the city. The highest rate of seat-belt use was reported in the centre while the lowest was in the east ( $92.5 \%$ and $65.3 \%$ respectively).

The overall rate of seat-belt use among front-seat passengers was $43.7 \%$. The use of seat-belts in pick-up trucks and van front-seat passengers was low (31.6\% and 30.0\% respectively) (Table 2). The highest rate of front-seat passengers' seat-belt use was on the highway and the lowest was in the eastern region (64.9\% and $34.3 \%$ respectively).

We analysed the relationship between demographic variables and the use of seat-belts among drivers. The results showed that there were significant relationships between seat-belt wearing and age $(P<0.002)$, sex $(P<$ $0.017)$, vehicle type $(P<0.001)$ and observation site $(P<0.001)$ (Table $2)$. Also the results obtained from chisquared tests showed significant relationships between front passengers' seat-belt wearing and seat-belt use by the drivers $(P<0.001)$, type of vehicle $(P<0.001)$ and observation site $(P<$ $0.001)$. There were no significant relationships for other variables studied (age $P<0.21$ and sex $(P<0.12)$ for passengers.

\section{Interview-based study}

In the second part of the study, 666 pedestrians were approached during the identified time for interviews. Of these, 62 respondents indicated that they never drove a vehicle. Thus the remaining 604 individuals took part in the study and were interviewed (no one refused to participate). The mean age of respondents was 33 (standard deviation 13.2) years old, and $74.5 \%$ were male (Table 3 ).

When we asked about the effectiveness of seat-belt in preventing injury, $81.2 \%$ said that seat-belts were very effective. Among people who had a driving license and used to drive, $62.4 \%$ stated that they always fastened their safety-belt while driving. Further analysis of the data showed significant relationships between geographic location of interview $(P<0.001)$, age $(P<0.001)$, sex $(P<0.001)$, education $(P<0.014)$ and self-reported seat-belt use while driving (Table 4). Also 55.6\% of respondents stated that they always used seat-belts as a front passenger. The results showed significant relationships between age $(P<$ $0.001)$, interview site $(P<0.001)$ and

\begin{tabular}{|c|c|c|c|c|}
\hline \multirow[t]{2}{*}{ Variable } & \multicolumn{2}{|c|}{$\begin{array}{l}\text { Drivers } \\
(n=7718)\end{array}$} & \multicolumn{2}{|c|}{$\begin{array}{l}\text { Front passengers } \\
\quad(n=3765)\end{array}$} \\
\hline & No. & $\%$ & No. & $\%$ \\
\hline \multicolumn{5}{|l|}{ Sex } \\
\hline Male & 6964 & 90.2 & 2370 & 62.9 \\
\hline Female & 756 & 9.8 & 1394 & 37.1 \\
\hline \multicolumn{5}{|c|}{ Estimated age (years) } \\
\hline $6-17$ & $\mathrm{n} / \mathrm{a}$ & - & 32 & 0.9 \\
\hline $18-20$ & 79 & 1.0 & 309 & 8.2 \\
\hline $21-35$ & 3512 & 45.5 & 1920 & 51.0 \\
\hline $36-55$ & 3501 & 45.4 & 1237 & 32.9 \\
\hline$\geq 56$ & 606 & 7.9 & 265 & 7.0 \\
\hline \multicolumn{5}{|l|}{ Type of vehicle } \\
\hline Taxi & 2197 & 28.5 & 1309 & 34.8 \\
\hline Private car & 4594 & 59.5 & 1985 & 52.7 \\
\hline Van & 251 & 3.3 & 158 & 4.2 \\
\hline Pick-up & 678 & 8.8 & 313 & 8.3 \\
\hline \multicolumn{5}{|c|}{ Observation site } \\
\hline North & 1140 & 14.8 & 494 & 13.1 \\
\hline South & 1400 & 18.1 & 806 & 21.4 \\
\hline West & 1400 & 18.1 & 457 & 12.1 \\
\hline East & 1420 & 18.4 & 927 & 24.6 \\
\hline Centre & 1260 & 16.3 & 591 & 15.7 \\
\hline Highway & 1100 & 14.2 & 490 & 13.0 \\
\hline
\end{tabular}

$n / a=$ not applicable. 


\begin{tabular}{|c|c|c|c|c|c|c|c|c|c|c|}
\hline \multirow[t]{4}{*}{ Variable } & \multirow{2}{*}{\multicolumn{4}{|c|}{$\begin{array}{c}\text { Drivers } \\
\text { Wearing seat-belt }\end{array}$}} & \multirow[t]{4}{*}{$P$-value } & \multirow{2}{*}{\multicolumn{4}{|c|}{$\begin{array}{l}\text { Front passengers } \\
\text { Wearing seat-belt }\end{array}$}} & \multirow[t]{4}{*}{$P$-value } \\
\hline & & & & & & & & & & \\
\hline & \multicolumn{2}{|c|}{ Yes } & \multicolumn{2}{|c|}{ No } & & \multicolumn{2}{|c|}{ Yes } & \multicolumn{2}{|c|}{ No } & \\
\hline & No. & $\%$ & No. & $\%$ & & No. & $\%$ & No. & $\%$ & \\
\hline Total & 6010 & 77.9 & 1708 & 22.1 & & 1647 & 43.7 & 1647 & 43.7 & \\
\hline Sex & & & & & $<0.017$ & & & & & 0.12 \\
\hline Male & 5398 & 77.5 & 1564 & 22.5 & & 1059 & 44.7 & 1311 & 55.3 & \\
\hline Female & 612 & 81.0 & 144 & 19.0 & & 587 & 42.1 & 807 & 57.9 & \\
\hline Estimated age (years) & & & & & $<0.002$ & & & & & 0.21 \\
\hline $6-17$ & $\mathrm{n} / \mathrm{a}$ & - & $\mathrm{n} / \mathrm{a}$ & - & & 13 & 40.6 & 19 & 59.4 & \\
\hline $18-20$ & 50 & 63.3 & 29 & 36.7 & & 127 & 41.4 & 182 & 58.9 & \\
\hline $21-35$ & 2782 & 79.2 & 730 & 20.8 & & 871 & 45.4 & 1049 & 54.6 & \\
\hline $36-55$ & 2696 & 77.0 & 804 & 23.0 & & 514 & 41.6 & 723 & 58.4 & \\
\hline$\geq 56$ & 469 & 77.4 & 137 & 22.6 & & 121 & 45.7 & 144 & 54.3 & \\
\hline Type of vehicle & & & & & $<0.001$ & & & & & $<0.001$ \\
\hline Taxi & 1799 & 81.9 & 398 & 18.1 & & 480 & 36.7 & 829 & 63.3 & \\
\hline Private car & 3700 & 80.6 & 892 & 19.4 & & 1023 & 51.5 & 962 & 48.5 & \\
\hline Van & 153 & 61.0 & 98 & 39.0 & & 50 & 31.6 & 108 & 68.4 & \\
\hline Pick-up & 358 & 52.8 & 320 & 47.2 & & 94 & 30.0 & 219 & 70.0 & \\
\hline Observation site & & & & & $<0.001$ & & & & & $<0.001$ \\
\hline North & 877 & 77.1 & 261 & 22.9 & & 179 & 36.2 & 315 & 63.8 & \\
\hline South & 1024 & 73.1 & 376 & 26.9 & & 432 & 53.6 & 374 & 46.4 & \\
\hline West & 1089 & 77.8 & 311 & 22.2 & & 193 & 42.2 & 264 & 57.8 & \\
\hline East & 927 & 65.3 & 493 & 34.7 & & 318 & 34.3 & 609 & 65.7 & \\
\hline Centre & 1166 & 92.5 & 94 & 7.5 & & 207 & 35 & 384 & 65.0 & \\
\hline Highway & 927 & 84.3 & 173 & 15.7 & & 318 & 64.9 & 172 & 35.1 & \\
\hline
\end{tabular}

$n / a=$ not applicable.

self-reported use of seat-belt as a front passenger.

The reasons for using and not using a safety-belt are shown in Table 5. Most of the respondents stated more than 1 reason. The most common reasons for wearing a seat-belt were avoiding fines (62.7\%), fear of injuries $(54.4 \%)$ and respecting the law (49.5\%). The most common reasons for not wearing a seat-belt were lack of risk awareness (51.4\%), lack of regulation awareness (40.4\%) and not being in the habit of wearing a seat-belt (40.4\%). About $15 \%$ of the people interviewed also indicated laziness or dirtiness or it not being necessary for short trips as other reasons for not wearing a safety seat-belt.

\section{Discussion}

This was a combination of an observational and an interview-based study. The findings showed that safety-belt use was low among drivers in Tehran and was lower still among front passengers. In general the use of vehicle seatbelts in the Islamic Republic of Iran is a very recent phenomenon. Using seat-belts by front and back passengers has been the law only since 2005. Thus we can argue although there have been improvements in using seat-belts in the country, still there is an urgent need for serious law enforcement and implementing educational programmes for those who neglect to use seat-belts.
We observed that about $90 \%$ of taxi drivers were wearing seat-belts which is considerably higher than a previous study from Tehran which reported that only $20 \%$ of taxi drivers were wearing seat-belts (17). Such different observations might be explained by several reasons. First, it could be the result of better law enforcement by police in recent years in the inner-city, particularly in the central areas. Secondly, changes to the type of vehicles used as taxi-cabs might be a factor. Taxis in Tehran were recently changed to newer, more modern cars. Thirdly, the geographical location of observations and type of vehicle also may explain why there were such differences in reports. Unfortunately, due to lack of information 


\begin{tabular}{|c|c|c|}
\hline Variable & No. & $\%$ \\
\hline \multicolumn{3}{|l|}{ Sex } \\
\hline Male & 450 & 74.5 \\
\hline Female & 154 & 25.5 \\
\hline \multicolumn{3}{|l|}{ Age (years) } \\
\hline $18-20$ & 32 & 5.3 \\
\hline $21-35$ & 381 & 63.1 \\
\hline $36-55$ & 172 & 28.5 \\
\hline$\geq 56$ & 18 & 3.0 \\
\hline \multicolumn{3}{|l|}{ Education } \\
\hline No education & 22 & 3.6 \\
\hline 6 years & 91 & 15.1 \\
\hline Diploma & 204 & 23.8 \\
\hline Upper diploma & 27 & 4.5 \\
\hline BA/BS degree & 202 & 33.4 \\
\hline $\mathrm{MA} / \mathrm{PhD}$ degree & 58 & 9.6 \\
\hline \multicolumn{3}{|l|}{ Interview site } \\
\hline North & 90 & 14.9 \\
\hline South & 96 & 15.9 \\
\hline West & 116 & 19.2 \\
\hline East & 95 & 15.7 \\
\hline Centre & 111 & 18.4 \\
\hline Highway & 96 & 15.9 \\
\hline
\end{tabular}

about these it is impossible to indicate to what extent these factors played a role.

Based on the observational study, women used seat-belts more than men while driving but used seat-belts less as front-seat passengers. Other investigators reported similar findings $(23,24)$. We observed that only $42.1 \%$ of women were wearing a seat-belt as a front passenger. This low rate of seat-belt use might be due to several reasons including embarrassment, types of women's clothing or concerns about the dirtiness of some safety-belts (as some citizens stated in interviews).

Interestingly we found that selfreported seat-belt use was lower than in direct observations (62.4\% versus $77.9 \%$ ), whereas previous researchers found that self-reported seat-belt use was overestimated $(25,26)$. This underestimation of seat-belt use in Tehran needs further investigation. addition, the current study found that avoiding fines was the main reason for seat-belt use. This clearly indicates that law enforcement is an effective measure for promoting safety in vehicles. The respondents also stated that there was no need to use safety-belts in the inner city and for short trips. This attitude has been noted in other studies (30), but considering that most of the road accident fatalities of Tehran Province occur in urban areas it is essential to plan training programmes to change this attitude.

Although the average rate of safetybelt use among drivers and front passengers in Tehran was close to $62 \%$ (77.9\% in drivers and $43.7 \%$ in front seat passengers), and has increased during recent years, it is still less than those reported from developed countries such as Australia, Finland and Germany, where over $90 \%$ of people use seat-belts (7).

This study had some limitations. The descriptive nature of the study could be a limitation. In addition, although we tried to obtain a large enough sample size in the study, it seems that studies of similar topics might need a bigger sample size. Another criticism of the sampling is that 62 respondents who did not drive were excluded from the interviews even though their opinions as passengers would also be valid. To interpret the findings with more precision it may be necessary to sample the expected volume of traffic/people at the time of observation. Finally, if possible, it would be better to observe and interview the same people to ensure that the interpretation of the results was more straightforward.

\section{Conclusions}

The findings showed that a considerable proportion of people in Tehran, whether drivers or front-seat passengers, do not use seat-belts. To improve 


\begin{tabular}{|c|c|c|c|c|c|c|c|c|c|c|c|}
\hline \multirow[t]{3}{*}{ Variable } & \multicolumn{10}{|c|}{ Use seat-belt } & \multirow[t]{3}{*}{$P$-value } \\
\hline & \multicolumn{2}{|c|}{ Never } & \multicolumn{2}{|c|}{ Seldom } & \multicolumn{2}{|c|}{ Sometimes } & \multicolumn{2}{|c|}{ Often } & \multicolumn{2}{|c|}{ Always } & \\
\hline & No. & $\%$ & No. & $\%$ & No. & $\%$ & No. & $\%$ & No. & $\%$ & \\
\hline Total & 4 & 0.7 & 27 & 4.5 & 48 & 7.9 & 148 & 24.5 & 377 & 62.4 & \\
\hline Sex & & & & & & & & & & & $<0.001$ \\
\hline Male & 1 & 0.2 & 17 & 3.8 & 37 & 8.2 & 128 & 28.4 & 267 & 59.3 & \\
\hline Female & 3 & 1.9 & 10 & 6.5 & 11 & 7.1 & 20 & 13.0 & 110 & 71.4 & \\
\hline Age (years) & & & & & & & & & & & $<0.001$ \\
\hline $18-20$ & 1 & 3.1 & 7 & 21.9 & 5 & 15.6 & 6 & 18.8 & 13 & 40.6 & \\
\hline $21-35$ & 1 & 0.3 & 14 & 3.7 & 30 & 7.9 & 105 & 27.6 & 231 & 60.6 & \\
\hline $36-55$ & 2 & 1.2 & 5 & 2.9 & 11 & 6.4 & 33 & 19.2 & 121 & 70.3 & \\
\hline$\geq 56$ & 0 & 0.0 & 0 & 0.0 & 2 & 11.1 & 4 & 21.2 & 12 & 66.7 & \\
\hline Education & & & & & & & & & & & $<0.014$ \\
\hline No education & 0 & 0.0 & 4 & 18.2 & 5 & 22.7 & 4 & 18.2 & 9 & 40.9 & \\
\hline 6 years & 2 & 2.2 & 6 & 6.9 & 4 & 4.4 & 29 & 31.9 & 50 & 54.9 & \\
\hline Diploma & 1 & 0.5 & 10 & 4.9 & 19 & 9.3 & 48 & 23.5 & 126 & 61.8 & \\
\hline Upper diploma & 0 & 0.0 & 0 & 0.0 & 2 & 7.4 & 8 & 29.6 & 17 & 63.0 & \\
\hline BA/BS degree & 0 & 0.0 & 6 & 3.0 & 16 & 7.9 & 48 & 23.8 & 132 & 65.3 & \\
\hline $\mathrm{MA} / \mathrm{PhD}$ degree & 1 & 1.7 & 1 & 1.7 & 2 & 3.4 & 11 & 19.0 & 43 & 74.1 & \\
\hline Interview site & & & & & & & & & & & $<0.001$ \\
\hline North & 1 & 1.1 & 4 & 4.4 & 11 & 12.2 & 20 & 22.2 & 54 & 60.0 & \\
\hline South & 0 & 0.0 & 5 & 5.2 & 9 & 9.4 & 57 & 59.4 & 25 & 26.0 & \\
\hline West & 0 & 0.0 & 8 & 6.9 & 7 & 6.0 & 21 & 18.1 & 80 & 69.0 & \\
\hline East & 1 & 1.1 & 4 & 4.2 & 5 & 5.3 & 25 & 26.3 & 60 & 63.2 & \\
\hline Centre & 1 & 0.9 & 2 & 1.8 & 5 & 4.5 & 3 & 2.7 & 100 & 90.1 & \\
\hline Highway & 1 & 1.0 & 4 & 4.2 & 11 & 11.5 & 22 & 22.9 & 58 & 60.4 & \\
\hline
\end{tabular}

\begin{tabular}{lcc}
\hline $\begin{array}{l}\text { Table } 5 \text { Citizens' reported reasons for using and not using vehicle seat-belts in the } \\
\text { interview study ( } n=\mathbf{6 0 4})\end{array}$ & No. \\
\hline Variable & 379 & 62.7 \\
Reasons for wearing seat-belt & 329 & 54.4 \\
Avoiding fines and penalties & 299 & 49.5 \\
Fear of injury & 245 & 40.5 \\
Respecting law & 184 & 30.4 \\
Importance of health & 87 & 14.4 \\
Awareness of severity of injury & 82 & 13.5 \\
Effectiveness of seat-belt & & \\
Seat-belt wearing is a sensible practice & 311 & 51.4 \\
Reasons for not wearing seat-belt & 244 & 40.4 \\
Lack of awareness of risks & 244 & 40.4 \\
Lack of awareness of regulations & 183 & 30.3 \\
Not in the habit of wearing seat-belt & 164 & 27.1 \\
It is uncomfortable and restricts movement & 113 & 18.7 \\
Embarrassment & 70 & 11.5 \\
Vehicle is not equipped with standard safety-belts & \\
It takes too much time to fasten &
\end{tabular}

Participants could choose more than 1 option. seat-belt use, we suggest that law enforcement accompanied by more public education should be seen as priority.

\section{Acknowledgements}

This paper originated from the $\mathrm{PhD}$ thesis of the first investigator at the Faculty of Medical Sciences, Tarbiat Modares University, Tehran, Islamic Republic of Iran. The authors are grateful to the Applied Research Department of Tehran Traffic Police, and to the observers, interviewers and all the participants who helped us in this work during the hot summer days of Tehran.

Funding: None.

Competing interests: None declared. 


\section{References}

1. Peden M, Scurfield R, Sleet D, Mohan D, Hyder A, Jarawan E, et al., editors. World report on road traffic injury prevention. Geneva: World Health Organization; 2004.

2. Saadat S, Soori H. Epidemiology of traffic injuries and motor vehicles utilization in the capital of Iran: a population based study. BMC Public Health. 2011;11:488. PMID:21693056

3. Resolution $64 / 255$. Improving global road safety. In: Sixtyfourth session of the United Nations General Assembly, 10 May 2010, Agenda item 46. New York: United Nations; 2010 (http://www.who.int/violence_injury_prevention/publications/road_traffic/UN_GA_resolution-54-255-en.pdf?ua=1, accessed 8 March 2014).

4. Petridou E, Moustaki M. Human factors in the causation of road traffic crashes. Eur J Epidemiol. 2000;16(9):819-26. PMID:11297224

5. Al-Haji G. Road Safety Development Index (RSDI): theory, philosophy and practice [dissertation no. 1100]. Linköping, Sweden: University of Linköping; 2007.

6. Salzberg P, Yamada A, Saibel C, Moffat J. Predicting seat belt use in fatal motor vehicle crashes from observation surveys of belt use. Accid Anal Prev. 2002 Mar;34(2):139-48. PMID:11829284

7. Seat-belts and child restraints: a road safety manual for decision-makers and practitioners. London: FIA Foundation for the Automobile and Society; 2009.

8. Moharamzad Y, Taghipour H, Hodjati Firoozabadi N, Hodjati Firoozabadi A, Hashemzadeh M, Mirjalili M, et al. Mortality pattern according to autopsy findings among traffic accident victims in Yazd, Iran. Chin J Traumatol. 2008 Dec;11(6):329-34. [English Edition] PMID:19032846

9. Khorasani-Zavareh D, Khankeh HR, Mohammadi R, Laflamme L, Bikmoradi A, Haglund BJ. Post-crash management of road traffic injury victims in Iran. Stakeholders' views on current barriers and potential facilitators. BMC Emerg Med. 2009;9:8. PMID:19435521

10. Haghparast Bidgoli H, Bogg L, Hasselberg M. Pre-hospital trauma care resources for road traffic injuries in a middle-income country-a province based study on need and access in Iran. Injury. 2011 Sep;42(9):879-84. PMID:20627291

11. Sasso RC, Meyer PR, Heinemann AW, Van Aken J, Hastie B. Seat-belt use and relation to neurologic injury in motor vehicle crashes. J Spinal Disord. 1997 Aug;10(4):325-8. PMID:9278918

12. Kashani AT, Shariat-Mohaymany A, Ranjbari A. Analysis of factors associated with traffic injury severity on rural roads in Iran. J Inj Violence Res. 2012 Jan;4(1):36-41. PMID:21502788

13. 13. Abbas AK, Hefny AF, Abu-Zidan FM. Seatbelts and road traffic collision injuries. World J Emerg Surg. 2011;6(1):18. PMID:21619677

14. HokmAbadi R. Jafari M, Souri H. Preparation of an Implementation Index to Measure Safety Performance of Roads in Iran. Iran J Epidemiol. 2009;5:7-13.

15. Mohammadi G. Prevalence of seat belt and mobile phone use and road accident injuries amongst college students in Kerman, Iran. Chin J Traumatol. 2011 Jun 1;14(3):165-9. PMID:21635804
16. Sehat M, Naieni KH, Asadi-Lari M, Foroushani AR, Malek-Afzali $\mathrm{H}$. Socioeconomic status and incidence of traffic accidents in metropolitan Tehran: a population-based study. Int J Prev Med. 2012 Mar;3(3):181-90. PMID:22448311

17. Shams M, Rahimi-Movaghar V. Risky driving behaviors in Tehran, Iran. Traffic Inj Prev. 2009 Mar;10(1):91-4. PMID:19214883

18. Casualty statistics of deaths and injuries resulting from traffic accidents referrals to Legal Medicine Organization [Internet]. Tehran: Iranian Legal Medicine Organization (in Farsi) (http:// www.Imo.ir, accessed 8 March 2014).

19. Behavioral risk factor surveillance system. 2011 draft questionnaire [Internet]. Bethesda (MD): Centers for Disease Control and Prevention; 2011 (www.cdc.gov/brfss/questionnaires/ pdf-ques/2011brfss.pdf, accessed 8 March 2014).

20. Brittle $\mathrm{C}$, Cosgrove M. Unconscious motivators and situational safety belt use: literature review and results from an expert panel meeting. Washington (DC): Office of Research and Technology, US National Highway Traffic Safety Administration; 2006 (DOT HS 810650).

21. Vivoda JM, Eby DW, St Louis RM, Kostyniuk LP. A direct observation study of nighttime safety belt use in Indiana. J Safety Res. 2007;38(4):423-9. PMID:17884429

22. Babbie E, editor. The practice of social research, 7th ed. Belmont (CA): Wadsworth; 1995.

23. Lerner EB, Jehle DV, Billittier AJ 4th, Moscati RM, Connery CM, Stiller G. The influence of demographic factors on seatbelt use by adults injured in motor vehicle crashes. Accid Anal Prev. 2001 Sep;33(5):659-62. PMID:11491246

24. Crandon IW, Harding HE, Branday JM, Simeon DT, Rhoden A, Carpenter R. The prevalence of seat belt use in Kingston, Jamaica: a follow-up observational study five years after the introduction of legislation. West Indian Med J. 2006 Oct;55(5):327-9. PMID:17373300

25. Ozkan T, Puvanachandra P, Lajunen T, Hoe C, Hyder A. The validity of self-reported seatbelt use in a country where levels of use are low. Accid Anal Prev. 2012 Jul;47:75-7. PMID:22326412

26. Parada MA, Cohn LD, Gonzalez E, Byrd T, Cortes M. The validity of self-reported seatbelt use: Hispanic and non-Hispanic drivers in El Paso. Accid Anal Prev. 2001 Jan;33(1):139-43. PMID:11189117

27. Nelson DE. Validity of self reported data on injury prevention behavior: lessons from observational and self reported surveys of safety belt use in the US. Inj Prev. 1996 Mar;2(1):67-9. PMID:9346059

28. Ibrahimova A, Shults RA, Beck LF. Comparison of 2008 national and state-level self-reported and observed seatbelt use estimates. Inj Prev. 2011 Jun;17(3):201-3. PMID:21393414

29. Lewis IM, Watson B, White KM, Tay R. Promoting public health messages: Should we move beyond fear-evoking appeals in road safety? Qual Health Res. 2007 Jan;17(1):61-74. PMID:17170244

30. Routley V, Ozanne-Smith J, Yu M, Wang J, Wu M, Zhang J, et al. Focus on seat belt use in China. Traffic Inj Prev. 2010 Dec;11(6):578-86. PMID:21128187 